\title{
CORRECTION
}

View Article Online

View Journal I View Issue

D) Check for updates

Cite this: RSC Adv., 2022, 12, 5768

rsc.li/rsc-advances

\section{Correction: Thermal, mechanical investigation and neutron shielding analysis for Gd-MOF/polyimide materials}

\author{
Chen Hu, ${ }^{\text {ab }}$ Qunying Huang ${ }^{\mathrm{a}}$ and Yutao Zhai ${ }^{\mathrm{a}}$ \\ Correction for 'Thermal, mechanical investigation and neutron shielding analysis for Gd-MOF/polyimide \\ materials' by Chen Hu et al., RSC Adv., 2021, 11, 40148-40158. DOI: 10.1039/D1RA07500D.
}

